\title{
Protective and Therapeutic Efficacy of Lactobacillus casei against Experimental Murine Infections due to Mycobacterium fortuitum Complex
}

\author{
By HAJIME SAITO, HARUAKI TOMIOKA* AND \\ KIYOFUMI NAGASHIMA \\ Department of Microbiology and Immunology, Shimane Medical University, Izumo 693, Japan
}

(Received 31 March 1987; revised 4 June 1987)

\begin{abstract}
A bacterial immunopotentiator, LC 9018 (heat-killed Lactobacillus casei), was studied for its protective and therapeutic efficacies against Mycobacterium fortuitum and $M$. chelonae infections in mice. This agent reduced the incidence of spinning disease and gross renal lesions and enhanced the elimination of organisms at the site of infection in the host mice, when administered intramuscularly six times a week $(0.1 \mathrm{mg}$ dry weight per injection, one injection on each day of treatment) from 1 week before to 2 weeks after infection. The LC 9018 injections in this protocol caused a marked increase in the phagocytic function, $\mathrm{O}_{2}^{-}$-producing ability and chemiluminescence of host peritoneal macrophages. Moreover, LC 9018 injections using the same schedule resulted in an enhancement of interleukin-1-producing function of the macrophages, particularly in the infected mice. These findings indicate that LC 9018 administration with the present protocol can activate macrophage functions, in particular those related to microbicidal activity. This would partly explain the protective and therapeutic efficacy of LC 9018 against infection due to $M$. fortuitum complex.
\end{abstract}

\section{INTRODUCTION}

Mycobacterium fortuitum complex ( $M$. fortuitum and $M$. chelonae) of Runyon's group IV is a potential pathogen causing pulmonary disease, soft tissue infections, osteomyelitis, dental infections, and so on (Tsukamura et al., 1983; Wolinsky, 1979). These infections are commonly encountered in compromised hosts whose resistance to infections is lowered due to impairment of immune functions (Wolinsky, 1979). Moreover, $M$. fortuitum complex is highly resistant to the majority of antituberculous and antimicrobial agents (Sanders et al., 1977). Therefore, the development of new antimycobacterial chemotherapeutics and immunopotentiators, which restore or enhance the lowered immune functions in compromised hosts, has long been awaited. Bacterial immunopotentiators such as BCG (Borsos \& Rapp, 1973; Mackaness, 1969), Corynebacterium parvum (Halpern et al., 1973; Miake et al., 1985), and penicillin-G-treated Streptococcus pygenes (OK-432) (Shiraishi et al., 1979) have been reported to enhance host resistance against microbial infections due to opportunistic pathogens. We also found that Lactobacillus casei (Kato et al., 1981) has a potent in vivo antimicrobial activity against experimental infections due to some opportunistic pathogens (Saito et al., 1980a, b, 1986 ; Sato, 1984; Watanabe \& Saito, 1986). In the present study, we investigated the protective and therapeutic efficacies of heat-killed L. casei YIT 9018 (LC 9018) against M. fortuitum complex infections in mice.

\footnotetext{
Abbreviations: FCS, foetal calf serum; HBSS, Hanks' balanced salt solution; MEM, Eagle's minimal essential medium; NBT, nitroblue tetrazolium; PMA, phorbol myristate acetate.
} 


\section{METHODS}

Mice. Female ddY, $\mathrm{C} 3 \mathrm{H} / \mathrm{He}$ or $\mathrm{CBA} / \mathrm{JN}$ mice (5 weeks old) purchased from Shizuoka Laboratory Animal Centre, Shizuoka, Japan, were used.

Organisms. M. fortuitum 18367 (from M. Tsukamura, National Chubu Hospital, Aichi, Japan) and M. chelonae subsp. abscessus 481 (from K. Takeya, Kyushu University, Fukuoka, Japan) were cultured in Dubos Tweenalbumin liquid medium (Wayne et al., 1964) at 37 and $33^{\circ} \mathrm{C}$, respectively.

Special agents. LC 9018 was donated by Yakult Central Institute for Microbiological Research, Tokyo, Japan, and OK-432 (penicillin-G-treated streptococcal preparation) was obtained from Chugai Pharmaceutical Co., Tokyo. Other agents were purchased from Wako Pure Chemical, except for the following: phytohaemagglutinin (Sigma), phorbol myristate acetate (PMA) (Sigma), lipopolysaccharide (LPS) from Escherichia coli O111:B4 (Difco), foetal calf serum (FCS) (M.A. Bioproducts Co.), Dubos Tween-albumin medium (Eiken Chemical Co.), Eagle's minimal essential medium (MEM) (Nissui Pharmaceutical Co.), Hanks' balanced salt solution (HBSS) (Nissui), RPMI 1640 medium (Nissui) and $\left[{ }^{3} \mathrm{H}\right]$ thymidine (New England Nuclear).

Experimental infections. Four- to five-day-old cultures of M. fortuitum or M. chelonae in Dubos Tween-albumin medium were given intravenously to ddY mice in doses of 2-9 $\times 10^{6}$ per mouse. LC 9018 or OK-432 dissolved in physiological saline was given intramuscularly six times a week (one injection on each day of treatment), from 1 week before the infection to 2 weeks after the infection, in a dose of $0.1 \mathrm{mg}$ dry weight per mouse per injection, unless otherwise specified. The animals were observed for the incidence of spinning disease due to severe inner ear infection (Saito \& Tasaka, 1969) for up to 4 weeks after infection. On day 28 , the mice were decapitated and the visceral organs were examined for gross lesions. The number of organisms recovered from the kidneys was counted on $1 \%$ Ogawa egg medium (Ogawa \& Saba, 1949).

Macrophage phagocytosis. Peritoneal cells $\left(2.5 \times 10^{6}\right.$ cells) from test mice were incubated for $2-3 \mathrm{~h}$ at $37^{\circ} \mathrm{C}$ in $1.0 \mathrm{ml}$ MEM containing $10 \%(\mathrm{v} / \mathrm{v}) \mathrm{FCS}$ in a $16 \mathrm{~mm}$ culture well (Corning) containing a $14 \mathrm{~mm}$ plastic culture sheet (Wako Pure Chemical) in a $\mathrm{CO}_{2}$ incubator $\left(5-10 \%, \mathrm{v} / \mathrm{v}, \mathrm{CO}_{2}\right.$ in air). After vigorous rinsing with HBSS, the macrophage monolayer culture on the $14 \mathrm{~mm}$ plastic sheet was immersed in $10 \%$ FCS-HBSS containing $10 \mu \mathrm{g}$ latex beads $(0.8 \mu \mathrm{m}) \mathrm{ml}^{-1}$, or $1 \times 10^{6}$ or $1 \times 10^{7}$ viable $M$. chelonae cells $\mathrm{ml}^{-1}$, and incubated in a $\mathrm{CO}_{2}$ incubator for $1 \mathrm{~h}$. The resultant macrophage monolayer culture was subjected to methylene blue (latex phagocytosis) or ZiehlToda (M. chelonae phagocytosis) (Toda, 1937) staining and the number of particles or bacilli ingested by macrophage cells was counted by microscopy.

$O_{2}^{-}$production by macrophages. Macrophage monolayer cultures prepared as above in $16 \mathrm{~mm}$ culture wells were incubated for $30 \mathrm{~min}$ at $37^{\circ} \mathrm{C}$ in HBSS containing $1 \mathrm{mg}$ nitroblue tetrazolium (NBT) $\mathrm{ml}^{-1}$, in the presence or absence of 10 or $100 \mathrm{ng} \mathrm{PMA} \mathrm{ml}^{-1}$ or $1 \times 10^{6}$ or $1 \times 10^{7}$ viable $M$. chelonae, and the percentage of cells with blue granules due to NBT reduction by $\mathrm{O}_{2}^{-}$was estimated by microscopy.

Chemiluminescence from macrophages. Peritoneal cells from test mice were suspended in $1 \mathrm{ml}$ HBSS containing $0.1 \mathrm{~mm}$-luminol at a concentration of $1 \times 10^{6}$ cells $\mathrm{ml}^{-1}$. After warming at $37^{\circ} \mathrm{C}$ for $1 \mathrm{~min}$, the photoemission was measured in a lumiphotometer (Lumicounter ATP-237, Toyo Kagaku Sangyo Co.) at intervals for up to $5 \mathrm{~min}$ after addition of PMA dissolved in $10 \mu 1$ dimethylsulphoxide to give a final concentration of $100 \mathrm{ng} \mathrm{m}^{-1}$.

Production of interleukin 1 by host macrophages. Peritoneal exudate cells induced by intraperitoneal infection of $M$. chelonae $\left(5 \times 10^{7}\right.$ per mouse $) 2$ weeks before harvest were incubated for $2-3 \mathrm{~h} \mathrm{in} 0.5 \mathrm{ml} 5 \%(\mathrm{v} / \mathrm{v})$ FCS-RPMI 1640 medium at $5 \times 10^{5}$ cells ml-1 in a $16 \mathrm{~mm}$ culture well in a $\mathrm{CO}_{2}$ incubator, and then rinsed with $1 \% \mathrm{FCS}-\mathrm{HBSS}$ to remove the non-adherent cells. The resultant macrophage monolayer was cultured for $24 \mathrm{~h}$ at $37^{\circ} \mathrm{C}$ in $1.0 \mathrm{ml} 5 \%$ FCS-RPMI 1640 medium, with or without $20 \mu \mathrm{g} \mathrm{LPS} \mathrm{ml}^{-1}$, in a $\mathrm{CO}_{2}$ incubator. The culture supernate was harvested and assayed for interleukin 1 activity, according to the method of Mizel et al. (1978). Briefly, thymocytes $\left(1.5 \times 10^{6}\right)$ from normal CBA/JN mice were cultured for $72 \mathrm{~h}$ at $37^{\circ} \mathrm{C}$ in $0.2 \mathrm{ml} 5 \%$ FBS-RPMI 1640 medium containing $1 \mu \mathrm{g} \mathrm{PHA} \mathrm{ml}{ }^{-1}$ and $25 \%(\mathrm{v} / \mathrm{v})$ of the culture supernate of macrophages, in a $\mathrm{CO}_{2}$ incubator. At $48 \mathrm{~h}$, $20 \mu \mathrm{l}[3 \mathrm{H}]$ thymidine $\left[2 \mathrm{Ci}(74 \mathrm{GBq}) \mathrm{mmol}^{-1}, 12.5 \mu \mathrm{Ci}(462.5 \mathrm{kBq}) \mathrm{ml}^{-1}\right.$ ] was added and the incorporated radioactivity was measured in a liquid scintillation counter after harvesting cells on to glass-fibre filter paper, using an automatic cell harvester.

\section{RESULTS}

\section{Protective and therapeutic effects of LC 9018 against $M$. fortuitum and $M$. chelonae infections}

The incidence of spinning disease in mice infected with either $M$. chelonae or $M$. fortuitum was suppressed by treatment with LC 9018, and a similar effect was noted for OK-432, another immunopotentiator used as a positive control (Fig. 1). In both infections, the inhibition was somewhat higher in the case of LC 9018. Both agents were efficacious in retarding the onset and in lowering the incidence of spinning disease. LC 9018 exhibited a similar efficacy whether given by the intramuscular, subcutaneous or intraperitoneal route (Fig. 2). It may be emphasized 


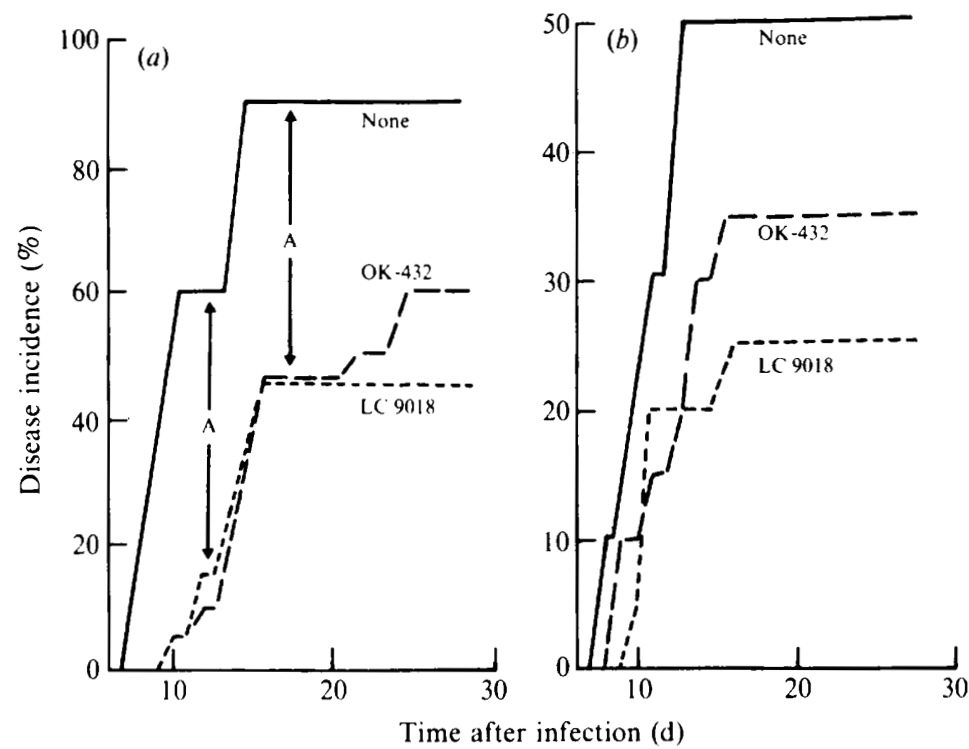

Fig. 1. Effects of LC 9018 and OK-432 on the incidence of spinning disease in mice infected with $M$. chelonae $(a)\left(2 \times 10^{7}\right.$ per mouse) or $M$. fortuitum $(b)\left(4.6 \times 10^{7}\right.$ per mouse). Mice (10 or 20 per regimen) were given or not given LC 9018 or OK-432 in a dose of $0.1 \mathrm{mg}$ dry weight per mouse per injection, once daily, six times a week from 1 week before to 2 weeks after infection by the intramuscular route. Arrows $A$ indicate a statistically significant difference $\left(P<0.05 ; \chi^{2}\right.$ test with Yates' modification).

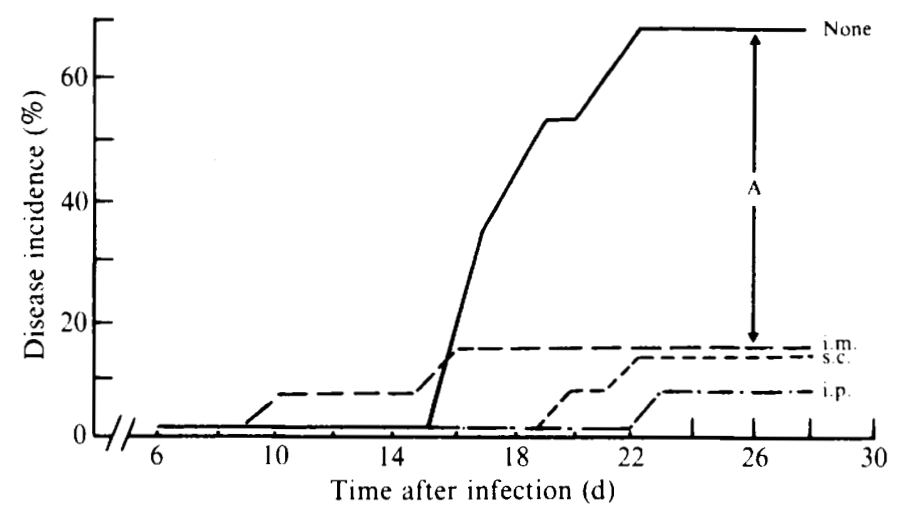

Fig. 2. Effect of LC 9018 given by various routes on the incidence of spinning disease in mice infected with $M$. chelonae $\left(3 \times 10^{7}\right.$ per mouse). LC 9018 was given to mice $(10$ or 20 per regimen) as described in Table 1, by the intramuscular (i.m.), subcutaneous (s.c.) or intraperitoneal (i.p.) route. Arrow A indicates a statistically significant difference $\left(P<0.01 ; \chi^{2}\right.$ test with Yates' modification).

that the present protocol for the treatment of mice with these agents was more efficacious than other protocols that were tested, such as daily injections for a week before infection, daily injections for a week before infection and two injections per week for two weeks after infection, and so on (unpublished observations). The reason for the difference in the severity of infection of the control mice between the experiments shown in Fig. $1(a)$ and Fig. 2 is not clear. It may have been due to variation in the susceptibility of the mice used in the experiments (which were done on different days), despite mice of the same sex and age, and from the same supplier, having been used. The possibility that the virulence of the inocula varied from experiment to experiment may be excluded, because the inocula were prepared from the same strain by identical procedures for each experiment. 
Table 1. Effects of LC 9018 and $O K-432$ on incidence of gross renal lesions and bacterial elimination at the site of infection in mice infected with $M$. chelonae

The results, recorded 4 weeks after infection, were taken from the experiment described in Fig. 1(a).

\begin{tabular}{|c|c|c|c|c|}
\hline \multirow[b]{2}{*}{ Administration } & \multirow{2}{*}{$\begin{array}{l}\text { No. of mice } \\
\text { with gross } \\
\text { renal lesions } \\
\text { per total mice }\end{array}$} & \multirow{2}{*}{$\begin{array}{l}\text { No. of organisms } \\
\text { recovered from } \\
\text { kidneys } \\
\text { (log c.f.u. })^{*}\end{array}$} & \multicolumn{2}{|c|}{ Organ weights $(\mathrm{g})^{*}$} \\
\hline & & & Spleen & Kidneys \\
\hline $\begin{array}{l}\text { None } \\
\text { LC } 9018 \\
\text { OK-432 }\end{array}$ & $\begin{array}{l}6 / 10 \\
0 / 20 \\
3 / 20\end{array}$ & $\begin{array}{l}2.34 \pm 0.74 \\
0.46 \pm 0.26 \\
0.63 \pm 0.26\end{array}$ & $\begin{array}{l}0.30 \pm 0.04 \\
0.22 \pm 0.01 \\
0.22 \pm 0.01\end{array}$ & $\begin{array}{l}0.36 \pm 0.01 \\
0.37 \pm 0.01 \\
0.36 \pm 0.01\end{array}$ \\
\hline
\end{tabular}

Table 1 shows the incidence of gross renal lesions and the number of organisms in the kidneys of mice infected with $M$. chelonae, with or without LC 9018 or OK -432 treatment, at 4 weeks after the infection. Both agents lowered the incidence of gross renal lesions and there was a reduction by approximately two orders of magnitude in the recovery of organisms from the kidneys. The spleen weight of infected mice was lowered in mice treated with these bacterial immunopotentiators but the difference from the untreated mice was not statistically significant. Similar results were obtained in the case of $\boldsymbol{M}$. fortuitum infection (data not shown).

Our findings indicate that both LC 9018 and OK-432 are efficacious in controlling experimental murine infections due to $M$. fortuitum complex. To elucidate the mechanisms of the protective and therapeutic effects of LC 9018, we studied the effect of the agent on host macrophage functions related to the expression of the host resistance to mycobacterial infections.

\section{Enhancement of function in normal macrophages by LC 9018}

To determine the functional state of host macrophages on the day of infection (day 0 ) in the above experimental infection studies (Figs 1 and 2, Table 1), the effects of LC 9018 on some cellular functions of host macrophages were studied. Table 2 shows the effects of the agent on macrophage phagocytic and $\mathrm{O}_{2}^{-}$-producing abilities. Daily (for one week) injections caused an increase in the phagocytic activity of host macrophages against latex beads and $M$. chelonae as well as in the stimulation of the PMA-triggered or phagocytosis-associated $\mathrm{O}_{2}^{-}$-producing ability of the host macrophages. In contrast, a single injection of LC $90187 \mathrm{~d}$ before macrophage harvest caused no such macrophage stimulation. Fig. 3 shows chemiluminescence of host macrophages of mice given or not given LC 9018 injections. The PMA-triggered chemiluminescence was significantly elevated only when the mice were given LC 9018 daily for one week. These findings indicate that the host macrophage functions related to their microbicidal ability were already enhanced by preinjections of LC 9018 (daily for one week) on the day of infection (day 0 ) in the experiments in Figs 1 and 2 and Table 1. It should be noted that the macrophageactivating effect of LC 9018 observed in this experiment is a systemic one, since the functions of peritoneal macrophages were augmented by intramuscular injections of the agent.

\section{Effects of LC 9018 on macrophage functions of host mice with $M$. chelonae infection}

Alteration of functions of host peritoneal macrophages due to $M$. chelonae infection and/or LC 9018 injections in the same protocol as described in the experimental infection studies in Figs 1 and 2 and Table 1 was studied. As shown in Table 3 (experiment 1), the phagocytic functions of host macrophages against both latex beads and $M$. chelonae cell were augmented either by infection or by LC 9018 injections. LC 9018 treatment of infected mice led to an additive increase in the phagocytic function of infected mice. Experiment 2 in Table 3 indicates that the macrophage phagocytosis-enhancing effect of LC 9018 was retained in an appreciable manner for at least 2 weeks after the cessation of LC 9018 administration. Both $M$. chelonae infection and LC 9018 injections caused a marked increase in the PMA-triggered $\mathrm{O}_{2}^{-}$-producing ability of host macrophages (Table 4). When infected mice were given LC 9018, a somewhat 


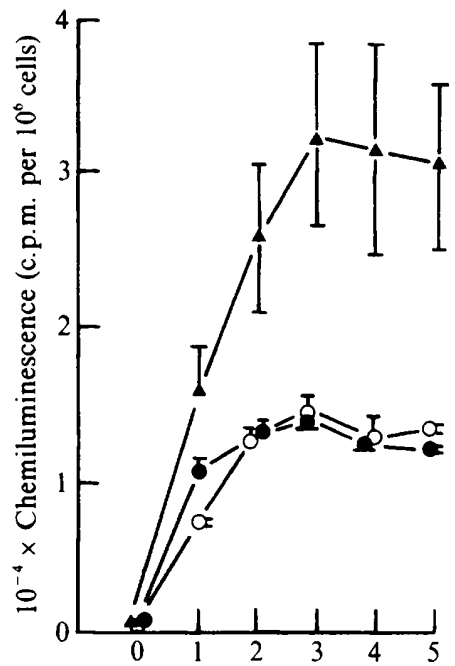

Time after PMA-triggering (min)

Fig. 3

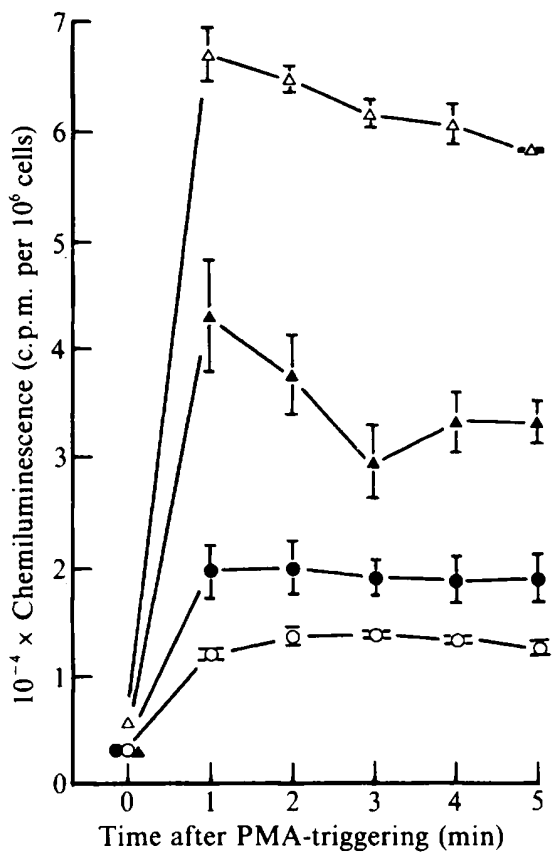

Fig. 4

Fig. 3. Effect of LC 9018 on chemiluminescence of host macrophages in response to triggering by PMA $\left(100 \mathrm{ng} \mathrm{m}^{-1}\right)$. LC 9018 was given to mice in a dose of $0.1 \mathrm{mg}$ per mouse per injection in a single injection ( $7 \mathrm{~d}$ before macrophage harvest) (O) or as daily injections ( $7 \mathrm{~d}$ to $1 \mathrm{~d}$ before harvest) (A); $O$, normal macrophages. Each symbol indicates the mean \pm SEM (two incubations of pooled cells).

Fig. 4. Effect of LC 9018 on PMA (100 $\left.\mathrm{ng} \mathrm{ml}^{-1}\right)$ triggered chemiluminescence of host macrophages with or without $M$. chelonae infection ( $2.2 \times 10^{7}$ per mouse). LC 9018 was given to mice as in Table 3 . Chemiluminescence was measured for macrophages from normal mice given $(\triangle)$ or not given $(O)$ LC 9018, and infected mice given $(\Delta)$ or not given (O) LC 9018. Each symbol indicates the mean \pm SEM (two incubations of pooled cells).

\section{Table 2. Effects of LC 9018 on some macrophage cell functions of normal mice}

The results are means \pm SEM (two incubations using pooled macrophages from four to six mice).

Phagocytosis

ingested objects per cell)

LC 9018

injection*

None

Single

(day -7)

Daily

(day -7 to day -1 )

$2 \cdot 25 \pm 0.09$
$\mathrm{O}_{2}^{-}$production $\dagger$ in the presence of:

\begin{tabular}{|c|c|c|}
\hline $\begin{array}{l}\text { No } \\
\text { trigger }\end{array}$ & $\begin{array}{c}\text { PMA } \\
\left(100 \mathrm{ng} \mathrm{ml}^{-1}\right)\end{array}$ & $\begin{array}{c}M . \text { chelonae } \\
\left(10^{6} \text { cells } \mathrm{ml}^{-1}\right) \ddagger\end{array}$ \\
\hline
\end{tabular}

\section{$M$. chelona}

$0.91+0.02$

$0.85 \pm 0.03$

$2 \cdot 16 \pm 0 \cdot 01$
$0.9 \pm 0.8$

$0 \cdot 3 \pm 0 \cdot 2$

0

0
$22 \pm 1$

$12 \pm 1$

$64 \pm 1$

$32 \pm 2$

* LC 9018 was given at a dose of $0.1 \mathrm{mg}$ per mouse per injection, in a single injection at $7 \mathrm{~d}$ before macrophage harvest or as daily injections from $7 \mathrm{~d}$ to $1 \mathrm{~d}$ before harvest.

$+\mathrm{O}_{2}^{-}$production of macrophages is represented as the percentage of NBT-reducing macrophages after $30 \mathrm{~min}$ incubation in the presence of the triggering substances indicated.

$\ddagger$ Similar results were obtained when $M$. chelonae cells were added at a dose of $1 \times 10^{7} \mathrm{ml}^{-1}$.

more enhanced $\mathrm{O}_{2}^{-}$production in response to PMA was observed. It may be noteworthy that $M$. chelonae infection alone enhanced the spontaneous $\mathrm{O}_{2}^{-}$-generating ability of host macrophages, although LC 9018 treatment abrogated this effect, presumably because it prevented the host mice from developing infection, which causes some severe inflammation leading to continuous 
Table 3. Effects of LC 9018 on the phagocytic ability of host macrophages with or without $M$. chelonae infection*

Mice given or not given LC 9018 by the intramuscular route once daily from day -7 to day 14 ; infected mice were injected intravenously with $M$. chelonae $\left(3.0 \times 10^{7}\right.$ and $3.5 \times 10^{7}$ organisms per mouse in experiments 1 and 2 , respectively) on day 0 . The results are means \pm SEM (two incubations of pooled macrophages from four to six mice).

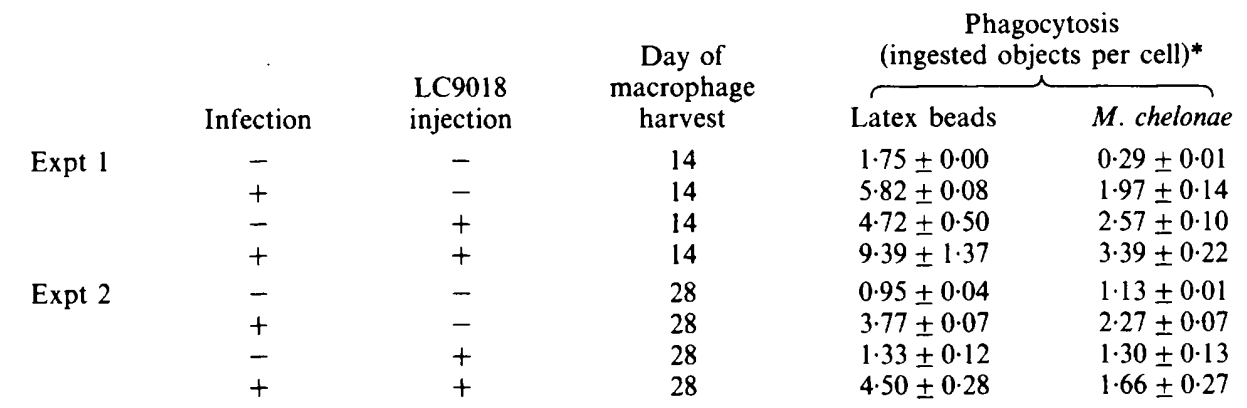

* Conditions as in Table 2, except that the phagocytic incubation mixture for experiment 2 contained $1 \times 10^{7}$ M. chelonae $\mathrm{ml}^{-1}$.

Table 4. Effect of LC 9018 on $\mathrm{O}_{2}^{-}$-producing ability of host macrophages with or without $M$. chelonae infection

Infection and LC 9018 injections were as in Table 3 except that the infection dose was $3 \times 10^{7}$ organisms per mouse. Macrophages were harvested $14 \mathrm{~d}$ after infection. The results are means \pm SEM $(n=2)$.

\begin{tabular}{|c|c|c|c|c|}
\hline \multirow[b]{2}{*}{ Infection } & \multirow{2}{*}{$\begin{array}{l}\text { LC } 9018 \\
\text { injection }\end{array}$} & \multicolumn{3}{|c|}{$\mathrm{O}_{2}^{-}$production (percentage of NBT-reducing macrophages) } \\
\hline & & No trigger & + PMA (10 ng ml-1) & + PMA (100 ng mi-1) \\
\hline- & - & 0 & $15 \pm 3$ & $24 \pm 5$ \\
\hline+ & - & $14 \pm 12$ & $37 \pm 9$ & $45 \pm 8$ \\
\hline- & + & $0.3 \pm 0.2$ & $45 \pm 4$ & $44 \pm 4$ \\
\hline+ & + & $0.8 \pm 0.3$ & $62 \pm 9$ & $49 \pm 4$ \\
\hline
\end{tabular}

irritation of the host macrophages. Fig. 4 shows PMA-triggered chemiluminescence of macrophages from mice given either $M$. chelonae infection or LC 9018 injections or both. LC 9018 injections augmented the responsiveness of host macrophages to PMA and this enhancing effect was greater than that caused by $M$. chelonae infection alone. The stimulating efficacy of LC 9018 against macrophage chemiluminescence in infected mice was much lower than that observed in normal mice.

Enhancement of interleukin-1-producing ability of host macrophages in response to LPS in mice given LC 9018

Table 5 shows the interleukin-1-producing ability of macrophages from host mice, with or without $M$. chelonae infection and/or LC 9018 injections. Although spontaneous interleukin 1 production was not affected in any of the cases, LPS-induced interleukin 1 production of host macrophages was markedly enhanced in mice with both infection and LC 9018 treatment. Infection or LC 9018 injections alone had little or no effect.

\section{DISCUSSION}

We investigated the protective and therapeutic efficacies of LC 9018 against experimental murine infections due to $M$. fortuitum complex and observed appreciable enhancement of host resistance by potentiation of the cellular functions of host macrophages related to microbicidal 
Table 5. Effect of LC 9018 on interleukin-1-producing ability of host macrophages with or without $M$. chelonae infection

Infection and LC 9018 injections were given in the same manner as described in Table 3, except that $5 \times 10^{7}$ organisms were injected intraperitoneally. Interleukin 1 activity in the supernatant of macrophage cultures with or without addition of LPS $\left(20 \mu \mathrm{g} \mathrm{ml}^{-1}\right)$ was measured on the basis of interleukin-1-dependent PHA mitogenesis of thymocytes; activity in a given sample is represented as $\left[{ }^{3} \mathrm{H}\right]$ thymidine incorporation to thymocytes (c.p.m. per culture well). The results are means \pm SEM (three incubations).

$\begin{array}{cccc}\text { Infection } & \begin{array}{c}\text { LC } 9018 \\ \text { injection }\end{array} & \overbrace{\text { Spontaneous }}^{\begin{array}{c}\text { Interleukin l activity } \\ \text { of macrophage culture supernatant }\end{array}} \\ - & - & 514 \pm 41 & \text { LPS-induced } \\ + & - & 675 \pm 37 & 4137 \pm 327 \\ - & + & 382 \pm 22 & 3436 \pm 344 \\ + & + & 588 \pm 14 & 5038 \pm 261 \\ & + & & 7292 \pm 198\end{array}$

capacity. Therefore, LC 9018 may be effective for clinical control of $M$. fortuitum complex infections, provided that this agent is administered to patients as precautionary injections, particularly in cases of immunocompromised hosts. Because LC 9018 is less toxic than the other bacterial immunopotentiators (Kato et al., 1981; Horikawa et al., 1986), it is more relevant for use in the clinical control of chronic infections. Some discrepancies were noted with respect to the effect of LC 9018 injections on the oxidative burst of host macrophages determined on the basis of $\mathrm{O}_{2}^{-}$-generating ability as compared with that measured on the basis of chemiluminescence of host macrophages (Table 2 versus Fig. 3; Table 4 versus Fig. 4). This is not so enigmatic for the following reasons. First, stimulation of $\mathrm{O}_{2}^{-}$-production by macrophages and by polymorphonuclear leucocytes in response to certain irritants is caused by an activation of NADPH oxidase located on the cell membrane of these phagocytic cell lineages (Dechatelet \& Shirley, 1981; Tsunawaki \& Nathan, 1984), presumably mediated by the elevation of protein kinase $\mathrm{C}$ activity linked to phosphatidylinositol turnover initiated by activation of specific receptors and membrane perturbation (Kiyotaki \& Bloom, 1984; Johnston \& Kitagawa, 1985). On the other hand, chemiluminescence of phagocytic cells originates not only from $\mathrm{O}_{2}^{-}$and $\mathrm{H}_{2} \mathrm{O}_{2}\left(\mathrm{H}_{2} \mathrm{O}_{2}\right.$ is rapidly generated by spontaneous or superoxide-dismutase-mediated dismutation of $\mathrm{O}_{2}^{-}$), but also from ${ }^{\circ} \mathrm{OH}$ and ${ }^{1} \mathrm{O}_{2}$, which are produced from the former active oxygen species via the Haber-Weiss reaction (Rosen \& Klebanoff, 1977; Sagone et al., 1977). Thus chemiluminescence reflects more complex cell events in macrophages than does $\mathrm{O}_{2}^{-}$production. Therefore, in certain macrophages in which cellular functions to produce $\mathrm{O}_{2}^{-}$and $\mathrm{H}_{2} \mathrm{O}_{2}$, but not ${ }^{\circ} \mathrm{OH}$ and ${ }^{1} \mathrm{O}_{2}$, were elevated, only an increase in the $\mathrm{O}_{2}^{-}$generation might be observed. This would explain the discordant changes in the NBT-reducing activity and chemiluminescence of macrophages from mice given double injections of LC 9018 and macrophages from mice given both $M$. chelonae infection and LC 9018 injections. Previously, we observed that during the course of Mycobacterium intracellulare infection the chemiluminescence and $\mathrm{H}_{2} \mathrm{O}_{2}$-generating abilities of murine macrophages changed in different ways (Saito et al., 1986a).

LC 9018 injections, particularly into $M$. chelonae-infected mice, increased the interleukin-1producing ability of the macrophages. Interleukin-1-producing ability is one of the important parameters representing macrophage activation (Meltzer \& Oppenheim, 1977). Therefore this result suggests that there is a systemic immunological activation of host macrophages due to LC 9018 injections. Since interleukin 1 is a mediator which activates helper T-cell functions in vivo (Farrar \& Hilfiker, 1982; Oppenheim et al., 1982), LC 9018 administration also possibly enhances $\mathrm{T}$-cell-mediated immune response to certain micro-organisms such as mycobacteria, acquired resistance to which is mainly dependent on cell-mediated immunity (Lowrie, 1983). In vivo activity of LC 9018 against $M$. fortuitum complex would be partly attributable to this mechanism. Effects of LC 9018 on host lymphocytes are now being investigated. 
We thank Yakult Central Institute for Microbiological Research, Tokyo, and Chugai Pharmaceutical Co., Tokyo, for providing LC 9018 and OK-432, respectively.

\section{REFERENCES}

Boros, T. \& RAPP, H. J. (editors) (1973). Conference on the use of BCG in therapy of cancer. National Cancer Institute Monograph no. 39.

Dechatelet, L. R. \& ShiRley, P. S. (1981). Pyridine nucleotide-dependent generation of hydrogen peroxide by a particulate fraction from human neutrophils. Journal of Immunology 126, 1165-1169.

FARRAR, J. J. \& Hilfiker, M. L. (1982) Antigennonspecific helper factors in the antibody response. Federation Proceedings 41, 263-268.

Halpern, B., Fray, A., Grepin, Y., Platic, O., Lorient, A. M., Rabourdin, A., Sparros, L. \& ISAC, R. (1973). Corynebacterium parvum, a potent immunostimulant in experimental infections and malignancies. In Immunopotentiation (Ciba Foundation Symposium 18 (new series)), pp. 217-236. Edited by P. Medawar. Amsterdam: Elsevier Excerpta Medica North-Holland.

Horikawa, Y., Saito, H. \& Watanabe, T. (1986). Effects of Lactobacillus casei on haematology and blood chemistry in normal and burned mice. Hiroshima Journal of Medical Sciences 35, 183-189.

JoHnston, R. B. \& Kitagawa, S. (1985). Molecular basis for the enhanced respiratory burst of activated macrophages. Federation Proceedings 44, 2927-2932.

Kato, I., Kobayashi, S., Yokokura, T. \& Mutai, M. (1981). Antitumor activity of Lactobacillus casei in mice. Gann 72, 517-523.

KiYOTAKI, C. \& BLOOM, B. R. (1984). Activation of murine macrophage cell lines. Possible involvement of protein kinases in stimulation of superoxide production. Journal of Immunology 133, 923-931.

LOWRIE, D. B. (1983). The macrophage and mycobacterial infections. Transactions of the Royal Society of Tropical Medicine and Hygiene 77, 646-655.

MACKANESS, G. B. (1969). The influence of immunologically commited lymphoid cells on macrophage activity in vivo. Journal of Experimental Medicine 129, 973-992.

Meltzer, M. S. \& Oppenheim, J. J. (1977). Bidirectional amplification of macrophage-lymphocyte interactions: enhanced lymphocyte activation factor production by activated adherent mouse peritoneal cells. Journal of Immunology 118, 77-82.

Miake, S., Nomoto, K., YoKokURa, T., YoshiKaI, Y., Mutal, M. \& Nomoto, K. (1985). Protective effect of Lactobacillus casei on Pseudomonas infection in mice. Infection and Immunity 48, 480-485.

Mizel, S. B., Oppenheim, J. J. \& RosenstReich, D. L. (1978). Characterization of lymphocyte-activating factor (LAF) produced by macrophage cell line, $\mathrm{P}^{388 \mathrm{D}_{1}}$. I. Enhancement of LAF production by activated $\mathrm{T}$ lymphocytes. Journal of Immunology 120 , 1497-1503.

OGAWA, T. \& SABA, K. (1949). The quantitative culture method for tubercle bacilli: on the case of cultivation of bacterial suspension. Kekkaku 24, 13-18 (in Japanese).

Oppenheim, J. J., Stadler, B. M., Siraganian, R. P., MAGE, M. \& MATHIESON, B. (1982). Lymphokines: their role in lymphocyte responses. Properties of interleukin 1. Federation Proceedings 41, 257-262.

Rosen, H. \& KLeBANOFF, S. J. (1977). Formation of singlet oxygen by myeloperoxidase mediated antimicrobial system. Journal of Biological Chemistry 252, 4803-4810.

Sagone, A. L., JR, Mendelson, D. S. \& Metz, E. N. (1977). The effect of sodium azide on the chemiluminescence of granulocytes. Evidence for the generation of multiple oxygen radicals. Journal of Laboratory and Clinical Medicine 89, 1333-1341.

SAITO, H. \& TASAKA, H. (1969). Comparison of the pathogenicity for mice of Mycobacterium fortuitum and Mycobacterium abscessus. Journal of Bacteriology 99, 851-855.

saito, H., Watanabe, T., Tomioka, H., Horikawa, Y. \& TADO, O. (1980a). Protection of mice against Staphylococcus aureus, Pseudomonas aeruginosa, and Escherichia coli with Lactobacillus casei. Medicine and Biology 100, 285-288 (in Japanese).

Saito, H., Watanabe, T., Horikawa, Y. \& Tado, O. $(1980 b)$. Resistance of mice treated with Lactobacillus casei against infections with Serratia marcescens, Klebsiella pneumoniae, and Candida albicans. Medicine and Biology 101, 29-32 (in Japanese).

SaIto, H., Tomioka, H., Yamada, Y. \& JidoI, J. $(1986 a)$. Oxidative and phagocytic functions of macrophages during infections induced in mice by Mycobacterium intracellulare and Listeria monocytogenes. Journal of General Microbiology 132, 11171125.

Saito, H., Watanabe, T. \& Horikawa, Y. (1986b). Effects of Lactobacillus casei on Pseudomonas aeruginosa infection in normal and dexamethasonetreated mice. Microbiology and Immunology 30, 249259.

Sanders, W. E., JR, Hartwig, E. C., Schneider, N. J., Cacciatore, R. \& Valdez, H. (1977). Susceptibility of organisms in the Mycobacterium fortuitum complex to antituberculous and antimicrobial agents. Antimicrobial Agents and Chemotherapy 12, 295-297.

SATO, K. (1984). Enhancement of host resistance against Listeria infection by Lactobacillus casei: role of macrophages. Infection and Immunity 44, 445-451.

Shiraishi, A., Mikami, Y. \& Arai, T. (1979). Protective effect of OK-432 (a streptococcal preparation) on experimental candidosis. Microbiology and Immunology 23, 549-554.

TODA, T. (1937). Improvement of the staining method for Mycobacterium tuberculosis and Mycobacterium leprae. Tokyo Iji Shinshi 3064, 3362 (in Japanese).

TSUKamura, M., Kito, K., Yamada, T. \& AkiYama, S. (1983). Lung disease due to Mycobacterium fortuitum (report of three cases). Kekkaku 58, 293-305 (in Japanese).

Tsunawaki, S. \& Nathan, C. F. (1984). Enzymatic basis of macrophage activation. Kinetic analysis of superoxide production in lysates of resident and activated mouse peritoneal macrophages and granu- 
locytes. Journal of Biological Chemistry 259, 43054312.

Watanabe, T. \& Saito, H. (1986). Protection of mice against Herpes Simplex virus infection by a Lactobacillus casei preparation (LC 9018) in combination with inactivated viral antigen. Microbiology and Immunology 30, 111-122.
Wayne, L. G., DoubeK, J. R. \& Russell, R. L. (1964). Classification and identification of mycobacteria. I. Tests employing Tween 80 as substrate. American Review of Respiratory Diseases 90, 588-597.

Wolinsky, E. (1979). Nontuberculous mycobacteria and associated diseases. American Review of Respiratory Diseases 119, 107-159. 